\title{
Implementasi Kurikulum Pembinaan Pendidikan Agama Islam di Rumah Tahanan Negara Kelas IIB Salatiga
}

\author{
Noor Malihah, Agus Wijayanto \\ IAIN Salatiga, BAPAS Kelas I Semarang, Indonesia \\ noormalihah_itab@yahoo.com,guswijay15@gmail.com
}

\begin{abstract}
The purpose of this research is to find out: 1). the implementation of curriculum in nurturing Islamic Education in the House of Detention IIB Salatiga. 2). the management of Islamic Education in the House of Detention IIB Salatiga prison. This research is a qualitative research and is a field research using a case study approach. The objects of this research are the head of the House of Detention, the inmates of the House of Detention IIB Salatiga, the officers of the House of Detention IIB Salatiga, the relevant documents used in House of Detention IIB Salatiga. The data are collected based on: interviews, documentation and data triangulation. The results of this research demonstrate that: the implementation of curriculum in nurturing Islamic Education for inmates in the House of Detention IIB Salatiga are based on a specific curriculum used a guide for Islamic spiritual advisers in the bouse of detention. The curriculum has been implemented properly so that the prisoner's mental revolution program can be achieved, though not all. Efforts to revolutionize the mentality and change the character of prisoners are conducted intensively and continously through lectures, discussions and counseling guidance and advice to the inmates. Coaching methods are carried out in two ways, namely inside and outside the room.
\end{abstract}

Keywords: Mental Revolution and the changing character of prisoners.

\begin{abstract}
Abstrak
Penelitian ini adalah penelitian kualitatif dan merupakan penelitian lapangan (field research) dengan menggunakan pendekatan studi kasus. Subyek penelitian ini adalah Kepala Rumah Tahanan Negara kelas IIB Salatiga, para pembina Pendidikan Agama Islam Rutan Salatiga, para warga binaan dan dokumen-dokumen Rumab Tahanan Negara kelas IIB Salatiga. Teknik pengumpulan data melalui observasi, wawancara, dokumentasi dan triangulasi data. Hasil penelitian yang telab dilakukan menunjukkan babwa: pembinaaan Pendidikan Agama Islam bagi Narapidana di Rutan Klas IIB Salatiga sudah menggunakan kurikulum sendiri sebagai pedoman bagi pembina Pendidikan Agama Islam di Rumab Tahanan Negara Salatiga dan sudah diterapkan dengan baik sehingga program revolusi mental narapidana dapat terlaksana dengan baik pula. Upaya untuk merevolusi mental dan perubahan karakter narapidana dilakukan pembinaan secara intensif dan terus-menerus melalui ceramah, kajian, diskusi dan bimbingan konseling serta nasehat terhadap warga binaan Rutan Salatiga. Metode pembinaan dilakukan dua cara yaitu di dalam dan di luar ruangan
\end{abstract}

Kata kunci: revolusi mental dan perubahan karakter narapidana.

Permalink/DOI: http://dx.doi.org/10.18326/infsl3v12i2.349-370 


\section{Latar Belakang Masalah}

Berbagai tindak kriminal seperti pencurian, penipuan, penggelapan, penganiayaan, pencabulan, perjudian, penyalahgunaan narkotika hingga tindak pidana korupsi dapat dengan mudah kita jumpai pada tayangan televisi maupaun secara langsung di sekitar kita. Apa yang kita dengar dan lihat tersebut mengacu kepada satu hal, yaitu karakter dan mental (Kristiawan, 2015:15). Berbagai fakta yang terjadi tersebut menunjukkan bahwa pendidikan karakter dan mental bagi masyarakat Indonesia sangat penting. Pendidikan secara sederhana dapat diartikan sebagai usaha manusia untuk membina kepribadian sesuai dengan nilai-nilai yang ada dalam masyarakat dan kebudayaan (Tim Dosen FIP IKIP Malang, 1980: 2). Dasar pendidikan atau pembinaan karakter dan mental pada dasarnya berangkat dari dasar religius yaitu yang terdapat dalam Qs At-Taubah ayat 122 (Departemen Agama RI, 1982: 164). Firman Allah SWT menerangkan bahwa tidak perlu semua orang mukmin berangkat ke medan perang, bila peperangan itu dapat dilakukan oleh sebagian kaum muslimin saja. Tetapi harus ada pembagian tugas dalam masyarakat, sebagian berangkat ke medan perang, dan sebagian lagi bertekun menuntut ilmu dan mendalami ilmu-ilmu agama Islam supaya ajaran-ajaran agama itu dapat diajarkan secara merata, dan dakwah dapat dilakukan dengan cara yang lebih efektif dan bermanfaat serta kecerdasan umat Islam dapat ditingkatkan.

Setiap manusia berhak mendapat pendidikan, (Levin, 1981: 2, sebagai bagian dari HAM. Pendidikan atau pembinaan tidak hanya dilakukan di sekolah saja. Pendidikan dapat dilakukan di keluarga dan masyarakat. Salah satu contoh pendidikan adalah pendidikan yang di berikan di Lembaga Pemasyarakatan atau Rumah Tahanan bagi para narapidana. Menurut Undang-Undang Pemasyarakatan Bab I pasal 1, yang dimaksud Lembaga Pemasyarakatan yang selanjutnya disebut LAPAS adalah tempat untuk melaksanakan pembinaan Narapidana dan Anak Didik Pemasyarakatan.

Pembinaan yang diberikan antara lain adalah pembinaan Pendidikan Agama Islam bertujuan untuk mengubah mental narapidana sehingga terjadi revolusi mental yang baik. Tujuan revolusi mental adalah mengubah cara pandang, pola pikir, sikap, perilaku dan cara kerja yang berorientasi pada kemajuan, 
serta membangkitkan kesadaran dan membangun sikap optimis dalam menatap masa depan sebagai masyarakat dengan kekuatan besar untuk berprestasi tinggi, produktif dan berpotensi menjadi diri yang maju (Indriyanto, 2014: 556). Nilai strategis dari revolusi mental yaitu menjadi diri yang jujur, dapat dipercaya, berkarakter, bertanggung jawab, kerja keras, optimis, produktif, inovatif dan berdaya saing. Apabila narapidana mengikuti program pembinaan dengan baik maka mereka akan mengalami revolusi mental dengan baik (Syakroa, 2016: 29).

Narapidana di Rutan Salatiga mayoritas beragama Islam namun adapula yang memeluk agama lain seperti Kristen, Katolik dan Budha, karena variasinya agama yang dipeluk oleh narapidana tersebut maka bimbingan rohani yang dilakukan di Rutan salatiga meliputi bimbingan Pendidikan Agama Islam dan bimbingan rohani Kristen. Sejauh ini bimbingan rohani Kristen cukup baik. Dalam satu minggu bisa 3-5 pertemuan . Sedang dalam bimbingan Islam tidak mencapai itu. Hal ini menjadi tantangan para pembimbing Pendidikan Agama Islam untuk lebih intensif dalam memberikan bimbingan rohani Islam bagi para narapidana. Dengan fenomena ini penulis tertarik untuk meneliti program tersebut terkait dengan kurikulumnya, tujuanya, evaluasinya, pengajarannya serta implementasi dari program tersebut dan capaianya sejauh mana pembinaan Pendidikan Agama Islam yang dilakukan di Rutan Salatiga terhadap Revolusi Mental Narapidana. Pembinaan yang dilaksanakan berdasarkan Sistem Pemasyarakatan bertujuan untuk mempersiapkan narapidana agar dapat berintegrasi secara sehat dengan masyarakat sehingga berperan kembali sebagai anggota masyarakat yang bebas dan bertanggung jawab. Adapun tujuan pemidanaan ada dua pandangan konseptual yang masing-masing mempunyai implikasi moral yang berbeda satu sama lain, yakni pandangan retributif (retributif view) dan pandangan utilitarian (utilitarian view) (Packer, 1968: 20).

\section{Kajian Pustaka}

Penelitian mengenai program pembinaan narapidana di Lembaga Pemasyarakatan telah dilakukan beberapa peneliti 
(Perdana, 2015; Astuti, 2011). Hasil penelitian yang mereka lakukan menyatakan bahwa dalam pelaksanaan pembinaan mental narapidana sesuai dengan ketentuan prosedur yang terdapat dalam PP No. 31 Tahun 1999 Tentang Pembinaan serta Undang-Undang N0. 12 Tahun 1995 Tentang Pemasyarakatan, dilaksanakan melalui pendidikan keagamaan yang meliputi pendidikan agama Islam, pendidikan agama Kristen dan Katolik serta latihan kepramukaan. Adapun hambatan yang dihadapi oleh petugas Lapas Wirogunan Yogyakarta dalam pelaksanaan pembinaan mental narapidana adalah kurangnya petugas pembinaan, keterbatasan dan transportasi untuk penceramah, serta ketidakaktifan narapidana dalam mengikuti kegiatan pembinaan mental.

Dari penelitian terdahulu di atas, penelitian yang dilakukan penulis sekarang berbeda dalam berbagai aspek. Pembinaan dalam penelitian ini bersifat lebih spesifik yaitu membahas kurikulum pembinaan Pendidikan Agama Islam narapidana dan manajemennya kaitannya dengan revolusi mental narapidana.

\section{Revolusi Mental}

Menurut Kementerian Koordinator bidang Pembangunan Manusia dan Kebudayaan, Revolusi mental merupakan suatu gerakan seluruh masyarakat (masyarakat dan rakyat) dengan cara yang cepat untuk mengangkat kembali nilai-nilai strategis yang diperlukan oleh bangsa dan negara untuk mampu menciptakan ketertiban dan kesejahteraan rakyat sehingga dapat memenangkan persaingan di era globalisasi. Revolusi mental mengubah cara pandang, pikiran, sikap, perilaku yang berorientasi pada kemajuan dan kemodernan, sehingga Indonesia menjadi bangsa besar dan mampu berkompetisi dengan bangsa-bangsa lain di dunia. Menurut pendapat Bung Karno "Revolusi Mental merupakan satu gerakan untuk menggembleng manusia Indonesia agar menjadi manusia baru, yang berhati putih, berkemauan baja, bersemangat elang rajawali, berjiwa api yang menyala-nyala".

Revolusi mental atau mental revolution adalah suatu konsep perubahan kearah peningkatan mutu dalam berbagai bidang 
kehidupan, termasuk dalam bidang pendidikan (Mulyasa, 2015: 24). Solusi revolusi mental ada dua cara yaitu dengan kembali kepada Tuhan dan pemulihan kemanusian (Agustinus, 2014: 10). Mental adalah sesuatu yang berkaitan dengan batin dan watak manusia yang bukan bersifat badan atau tenaga. Secara umum mental mencakup beberapa hal yaitu sikap kepribadian yang baik terhadap diri sendiri, perkembangan serta pertumbuhan diri, dan keseimbangan mental, kesatuan pandangan dan ketahanan terhadap segala tekanan (Kristiawan, 2015: 15).

\section{Program Pembinaan}

Pengertian pembinaan menurut pengertian yang tercantum pada Kamus Besar Bahasa Indonesia (1994), pembinaan adalah halhal yang meliputi: suatu proses, pembaharuan, usaha/tindakan dan kegiatan yang dilakukan secara berdaya guna dan berhasil guna untuk mendapatkan hasil yang lebih baik (Poerwodarminta, 1987: 56).

Dalam hal ini menunjukan adanya kemajuan, peningkatan, pertumbuhan, evolusi, atas berbagai kemungkinan, berkembangnya, atau meningkatnya sesuatu. Disini terdapat dua unsur pengertian, yakni pembinaan dari suatu tujuan dan yang kedua pembinaan dapat menunjukkan kepada "perbaikan" atas sesuatu (Miftah, 2003: 22), bagi terciptanya manusia yang terampil, cakap dan terpupuk sikap mental yang positif dimana pengembangan diselaraskan dengan nilai yang dianut (Munandar, 1993: 33).

Program pembinaan narapidana adalah semua usaha yang ditujukan untuk memperbaiki dan meningkatkan akhlak (budi pekerti) para narapidana dan anak didik yang berada di dalam Lembaga Pemasyarakatan/Rumah Tahanan Negara.

Pembinaan narapidana dilakukan secara terus menerus sejak narapidana masuk dalam rutan. Sistem pemasyarakatan merupakan suatu proses pembinaan warga binaan sebagai makhluk Tuhan, individu dan sebagai masyarakat. Dalam pembinaan, narapidana dikembangkan keadaan jasmani, rohani serta kemasyarakatannya dan dibutuhkan pula elemen-elemen yang berkaitan untuk mendukung keberhasilan dalam pembinaan. Menurut pasal $20 \mathrm{UU}$ 
No 12 Tahun 1995 tujuan pembinaan adalah membentuk warga binaan pemasyarakatan agar menjadi manusia seutuhnya, menyadari kesalahannya, memperbaiki diri dan tidak mengulangi tindak pidana sehingga dapat diterima kembali oleh lingkungan masyarakat, dapat aktif berperan dalam pembangunan dan dapat hidup secara wajar sebagai warga yang baik dan bertanggung jawab. Selain itu dalam pribadi narapidana diharapkan mampu mendekatkan diri pada Tuhan sehingga dapat memperoleh keselamatan baik didunia maupun akhirat.

\section{Kurikulum}

Secara umum pengertian kurikulum adalah suatu perangkat mata pelajaran atau program pendidikan yang diberikan oleh suatu lembaga penyelenggara pendidikan yang berisi rancangan pelajaran yang akan diberikan kepada peserta pelajaran dalam satu periode jenjang pendidikan (Dewantoro, 2003: 49). Hilda Taba berpendapat bahwa kurikulum sebagai a plan for learning, yakni sesuatu yang direncanakan untuk dipelajari oleh siswa. Sementara itu, pandangan lain mengatakan bahwa kurikulum sebagai dokumen tertulis yang memuat rencana untuk peserta didik selama di sekolah. Kurikulum adalah suatu rencana pembelajaran di bawah bimbingan dan tanggunga jawab sekolah atau lembaga pendidikan beserta staf pengajarnya yang disusun untuk melancarkan proses belajar mengajar (Nasution, 2008: 3). Nasution juga menjelaskan adanya 4 komponen kurikulum, yaitu (i) tujuan, (ii) isi/materi pelajaran, (iii) Komponen Metode/ Strategi, dan (iv) evaluasi.

\section{Pendidikan Agama Islam dan Pembinaan Agama Islam}

Pendidikan Agama Islam

Arti dari Pendidikan Agama Islam adalah Usaha untuk hidup iman, sebab pada dasarnya hidup merupakan penyerahan diri penuh kepada Tuhan (Darminta, 2006: 16. Secara umum Islam adalah Agama wahyu yang diterima langsung oleh Nabi Muhammad SAW. diyakini dapat menjamin terwujudnya kehidupan manusia yang 
sejahtera lahir dan batin. Dalam Al-Quran ditegaskan bahwa Allah SWT telah menganugerahkan kepada manusia suatu kelebihan dan keutamaan di atas makhluk lainnya yaitu fitrah, kebebasan, ruh yang kekal, dan akal.

Pendidikan Agama Islam, adalah upaya sadar dan terencana dalam menyiapkan peserta didik untuk mengenal, memahami, menghayati, hingga mengimani ajaran agama Islam, dibarengi dengan tuntunan hukum syariat dan menghormati penganut agama lain dalam hubungannya dengan kerukunan antar ummat beragama hingga terwujud kesatuan dan persatuan bangsa (Majid, 2006). Menurut Gholib (2006: 29), tujuan dari Pendidikan Agama Islam antara lain adalah (i) Mengembangkan wawasan spiritual yang semakin mendalam, (ii) Membekali anak muda dengan berbagai pengetahuan dan kebaikan, (iii) Membantu peserta didik yang sedang tumbuh untuk belajar berpikir secara logis dan membimbing proses pemikirannya, (iv) Mengembangkan wawasan relasional dan lingkungan sebagaimana yang dicita-citakan dalam Islam, dengan melatih kebiasaan dengan baik.

Armai Arief mengutip pendapat Mohammad Al Toumy Al Syaibani (2002: 25-26) tentang tujuan pembinaan keagamaan mempunyai tahapan-tahapan yaitu (i) Tujuan individual, (ii) Tujuan ini berkaitan dengan masing-masing individu dalam mewujudkan perubahan yang dicapai pada tingkah laku dan aktifitasnya, (iii) Tujuan social, (iv) Tujuan ini berkaitan dengan kehidupan masyarakat sebagai keseluruhan dan tingkah laku mereka secara umum, dan (v) Tujuan professional.

Pembinaan kerohanian islam dalam konteks keagamaan bertujuan untuk menumbuhkan kesadaran dan memelihara norma agama secara terus-menerus agar perilaku hidup manusia senantiasa berada pada tatanan. Namun secara garis besar, arah atau tujuan dari pembinaan keagamaan adalah meliputi dua hal, yaitu (i) Tujuan yang berorientasi pada kehidupan akhirat, yaitu membentuk seorang hamba yang bertakwa kepada Allah Swt; dan (ii) Tujuan yang berorientasi pada kehidupan dunia, yaitu membentuk manusia yang mampu menghadapi segala bentuk kebutuhan dan tantangan kehidupan agar hidupnya lebih layak dan bermanfaat bagi orang lain. 
Dalam Al Qur'an surat Al Qashash: 77, Allah Swt menyuruh kepada semua hamba-Nya agar mencari kebahagiaan akhirat dengan cara beribadah kepada Allah Swt. Tetapi manusia tidak boleh melupakan kebahagiaan dunia, oleh sebab itu manusia disuruh untuk bekerja guna memenuhi kehidupan selama masih hidup di dunia.

Kurikulum Pendidikan Agama Islam (PAI) sebagaimana dimuat dalam Peraturan Menteri Agama (Permenag) Nomor 2 Tahun 2008 yang berjudul Standar Kompetensi Lulusan dan Standar Isi Pendidikan Agama Islam dan Bahasa Arab di Madrasah merinci kurikulum tersebut dalam enam bab dengan perincian yang sangat detail.

\section{Pembinaan PAI}

Berbagai definisi tentang pembinaan telah didiskusikan oleh banyak ahli. Salah satunya, Thoha (2003) menyatakan bahwa pembinaan adalah sebagai suatu tindakan, proses, hasil, atau pernyataan menjadi lebih baik. Dalam hal ini menunjukan adanya kemajuan, peningkatan, pertumbuhan, evolusi, atas berbagai kemungkinan, berkembangnya, atau meningkatnya sesuatu.

Landasan pembinaan PAI telah dijelaskan dalam ajaran-ajaran Islam yang bersumber dari Al-Qur'an dan Hadits Samsul (2002). Syihab (2005:63) mengemukakan bahwa dalam Surat Ali Imran Allah SWT. Mengangkat derajat ummatnya yang berilmu, bahkan ayat pertama yang diturunkan oleh Allah SWT melalui malaikat Jibril kepada Nabi Muhammad SAW. bukanlah ayat yang menerangkan tentang shalat, puasa, ataupun zakat, melainkan perintah "Iqra" yaitu membaca, menelaah, merenungkan, dan mengkaji yang merupakan salah satu upaya dalam mencerdaskan manusia melalui pembinaan atau pendidikan.

\section{Metode Penelitian}

Penelitian ini termasuk penelitian kualitatif dan merupakan penelitian lapangan (field research) dengan menggunakan pendekatan studi kasus. Objek dalam penelitian ini adalah narapidana, Pembina PAI dan Kepala Rumah Tahanan Negara Salatiga. 
Teknik pengumpulan data adalah dengan observasi, dokumentasi dan wawancara. Observasi untuk mendapatkan gambaran kegiatan pembinaan PAI yang berlangsung di Rumah Tahanan Negara Salatiga dari berbagai aktifitas narapidana, pengajar dan peran Kepala Rumah Tahanan Negara Salatiga dalam mewujudkan revolusi mental narapidana.

Selanjutnya adalah dokumentasi yaitu dengan melihat dokumen pembinaan, diantaranya Kartu Pembinaan yang mencakup tahap-tahap pembinaan, Buku Perwalian untuk melihat perkembangan narapidana yang dilaksanakan oleh wali pemasyarakatan, Litmas (Penelitian Masyarakat) dilaksanakan oleh petugas Balai Pemasyarakatan dengan cara melakukan kegiatan home visit ke rumah penjamin narapidana yang telah di usulkan program pembinaan PB (Pembebasan Bersyarat), CB (Cuti Bersyarat), CMB (Cuti Menjelang Bebas) dan CMK (Cuti Mengunjungi Keluarga)

Wawancara adalah teknik untuk mendapatkan data tertulis yang berisi wawancara dengan narapidana, pembina PAI, dan Kepala Rumah Tahanan Negara Salatiga mengenai pembinaan PAI untuk mewujudkan revolusi mental.

Teknik analisis data adalah dengan menggunakan analisis model Miles and Huberman. Analisis data kualitatif dilakukan secara interaktif dan berlangsung terus menerus sampai tuntas (Sugiono,2004: 337). Model analisis ini terdiri dari tiga komponen yaitu reduksi data, penyajian data dan penarikan kesimpulan dengan melakukan verifikasi kepada Kepala Rumah Tahanan Negara Salatiga.

\section{Analisis}

\section{Tujuan Kurikulum PAI di Rutan Salatiga}

Tujuan kurikulum PAI secara garis besar tertuang dalam buku pedoman Taman Pendidikan Al Qur'an At Taubah Rutan Salatiga, disusun oleh staf pelayanan tahanan bagian kerohanian Islam Rutan Salatiga yang bertujuan (1) membentuk karakter warga binaan pemasyarakatan menjadi lebih baik, (2) membentuk karakter warga 
binaan pemasyarakatan yang mandiri dan memiliki daya saing berlandaskan iman, taqwa, ilmu pengetahuan dan teknologi, serta (3) mendorong terciptanya umat yang berakhlak mulia. Dengan tujuan yang tertuang di buku tersebut, diharapkan setelah bebas dari Rutan, warga binaan pemsyarakatan tersebut dapat diterima di tengah-tengah masyarakat dengan baik.

Landasan pengambilan tujuan tersebut terdapat di dalam Al Qur'an surat Ar-Ra'du : 11, yang berbunyi:

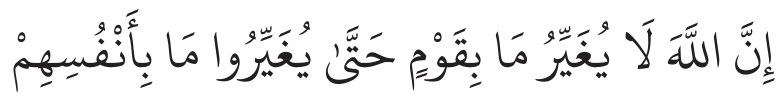

Artinya: "Sesungguhnya Allah tidak merubah keadaan sesuatu kaum sehingga mereka merubah keadaan yang ada pada diri mereka sendiri." (QS. Ar-Ra'du : 11)

Ayat di atas mengandung pengertian bahwa Allah SWT menyuruh kepada semua hamba Nya agar manusia berusaha untuk menjadi lebih baik. Tujuan tersebut di atas telah sesuai dengan tujuan revolusi mental dan tujuan PAI. Misalnya pada tujuan (1) yang bermaksud menjadikan warga binaan pemsyarakatan memiliki karakter yang lebih baik, jelaslah bahwa aka nada proses perubahan menjadi lebih baik yang berarti telah terjadi revolusi mental. Di tujuan ke (2), warga binaan pemasyarakatan diharapkan dapat mandiri dan berdaya saing berlandaskan iman dan takwa serta ilmu pengetahuan dan teknologi.. Hal ini sesuai dengan tujuan revolusi mental bahwa dalam proses revolusi mental terdapat ide kreatif, inovatif seperti pemanfaatan teknologi yangnantinya menjadi bekal mereka untuk bersaing dalam masyarakat. Serta dituliskan pula di tujuan bahwa warga binaan tersebut harus tetap melandaskan kehidupan mereka berdasarkan iman dan takwa. Maka jelaslah, ada tatanan, aturan yang nantinya akan mengatur dan menjadikan para warga binaan pemasyarakatan tersebut menjadi lebih baik, jujur dan bertanggung jawab sesuai keimanan dan ketakwaannya, dalam hal ini sesuai dengan ajaran Islam. Hal ini menunjukkan bahwa Rutan Salatiga berprinsip untuk melakukan revolusi mental yang pada intinya adalah melakukan perubahan seseorang baik dari perilakunya maupun sikapnya, juga mengharapkan narapidana 
memiliki bekal pengetahuan yang berarti ada proses revolusi mental untuk menjadikan sesorang produktif dan inovatif serta berdaya saing

\section{Materi/isi dari kurikulum di Rutan Salatiga}

Kurikulum Pembinaan Pendidikan Agama Islam di RUTAN Salatiga yang berjudul Standar Kompetensi dan Standar Isi Pembinaan Pendidikan Agama Islam terdiri dari 2 bab dengan perincian sebagai berikut bab I berisi tentang Al-Qur'an-Hadis, Akidah-Akhlak, Fikih, dan Sejarah Kebudayaan Islam. Sementara Bab II, berkenaan dengan Standart Kompetensi (SK) dan Kompetensi Dasar (KD) Pembinaan Pendidikan Agama Islam yang memuat tentang (i) Latar belakang tentang perlunya pembinaan Pendidikan Agama Islam dengan mengacu pada tujuan kurikulum PAI Rutan Salatiga dan UU Nomor 20 Tahun 2003 tentang system Pendidikan Nasional, (ii) Tujuan masing-masing mata pelajaran antara lain: Al-Qur'anHadist, Fikih, dan Aqidah akhlak, Sejarah Kebudayaan Islam dan (iii) Ruang lingkup dari masing-masing mata pembinaan pelajaran Agama Islam tersebut yang pada dasarnya sama dengan deskripsi yang terdapat dalam struktur kurikulum.

Standart Kompetensi dan Kompetensi Dasar untuk masingmasing mata pelajaran Pembinaan PAI tersebut yang disusun sesuai dengan hakikat dari standart kompetensi dan kompetensi dasar tersebut.

\section{Metode}

Metode pembinaan PAI di Rutan Salatiga bagi narapidana dibagi menjadi dua bagian. Yang pertama adalah Proses pembelajaran di dalam ruangan/kelas. Proses pembelajaran di ruangan merupakan proses pembelajaran yang sangat efektif dari segi waktu dan tempatnya. Sehingga dalam penyampaian materi oleh Pembina / pengajar dapat diterima dengan baik dan mudah oleh narapidana dengan menggunakan metode tanya jawab, metode demonstrasi, metode diskusi, metode belajar dari pengalaman, metode iqro' dan metode sima'i. 
Berikutnya adalah proses pembelajaran di luar kelas. Metodenya antara lain metode keteladanan, metode pembiasaan dan metode konseling agama Islam. Kegiatan yang dilakukan oleh pihak RUTAN antara lain (i) Pengajian/ kajian keislaman yang diadakan setiap hari Senin, Selasa, Rabu, Sabtu pukul 10.30-12.00 WIB, (ii) pengajaran iqro dan al-qur'an diadakan setiap hari kamis pada pukul 10.30-12.00 WIB, (iii) Peringatan hari besar agama Islam diadakan pada saat momen hari besar agama Islam seperti Idul Fitri, Idul Adha, Maulid Nabi Muhammad, Isra' dan Mi'raj.

\section{Evaluasi}

Untuk proses evaluasi di Rutan Salatiga dilakukan dua kegiatan yaitu pemantauan dan evaluasi. Pemantauan yang dilakukan terhadap proses pembinaan Pendididkan Agama Islam dilakukan dengan cara (i) Pemantauan proses pembinaan dilakukan pada tahap perencanaan, pelaksanaan, dan penilaian hasil pembinaan, (ii) Pemantauan dilakukan dengan cara diskusi kelompok terfokus, pengamatan, pencatatan, perekaman, wawacara, dan dokumentasi, (iii) Kegiatan pemantauan dilaksanakan oleh kepala dan pengawas satuan pendidikan dalam hal ini TPP (Tim Pengamat Pemasyarakatan).

Adapaun evaluasi dilakukan dengan dua cara. Yang pertama adalah evaluasi proses pembelajaran dilakukan untuk menentukan kualitas pembelajaran secara keseluruhan, mencakup tahap perencanaan proses pembinaan, pelaksanaan proses pembinaan, dan penilaian hasil pembinaan. Yang kedua adalah evaluasi proses pembinaan diselenggarakan dengan cara (i) membandingkan proses pembinaan yang dilaksanakan guru ngaji/ustadz ustadzah dengan standar proses, (ii) mengidentifikasi kinerja pengajar dalam proses pembinaan sesuai dengan kompetensi pengajar/ustad ustadzahnya. Yang ketiga adalah evaluasi proses pembinaan memusatkan pada keseluruhan kinerja guru dalam proses pembinaan. Yang berikutnya evaluasi berupa pelaporan dan tindak lanjut. Hasil pemantauan, supervisi dan evaluasi proses pembinaan dilaporkan kepada kepala Rutan yang nantinya jika diperlukan tindak lanjut, maka akan dilakukan penguatan dan penghargaan diberikan 
kepada narapidana yang telah memenuhi standar pembinaan PAI di Rutan Salatiga berupa sertifikat dan sebagai syarat pemberian PB (Pembebasan Bersyarat). Sedangkan bagi warga binaan yang tidak memenuhi standar diberikan teguran dan sanksi berupa hukuman fisik yang bersifat membangun.

\section{Analisa Kelebihan}

Berdasarkan paparan tersebut di atas, tentang Kurikulum PAI pada Narapidana di Rutan Salatiga memiliki beberapa kelebihan diantaranya sebagai berikut; a) Telah memenuhi kebutuhan materi kurikulum untuk tingkat Narapidana. Dengan demikian kurikulum tersebut dapat dikatakan sudah lengkap, dan digunakan sebagai acuan dalam menyusun silabus pembinaan Pendidikan Agama Islam. b) Standar kompetensi lulusan untuk seluruh mata pelajaran pembinaan Pendidikan Agama Islam (PAI), untuk Narapida sebagai binaan yang berciri khas keislaman, yakni memuat mata pelajaran Al-Qur'an-Hadis, Akidah-Akhlak, Fikih, Sejarah Kebudayaan Islam, tersebut sudah dirumuskan dengan cara cukup sistematis, saling berkaitan, sesuai dengan tingkatannya dan kebutuhan materi untuk seorang narapidana yang sangat membutuhkan pembinaan akhlak untuk menjadi baik. c) Sudah terdapat perbedaan standar kompetensi yang dan jelas untuk setiap tingkat atau jenjang pendidikan, umur dan kemampuan pemahaman agama. d) Seluruh Materi dalam kurikulum tersebut pada Rutan Salatiga ditujukan selain untuk memberikan pemahaman, wawasan tentang ajaran Islam, juga dalam rangka menghayati dan mengamalkan ajaran Islam tersebut, sehingga pembinaan PAI tersebut akan nampak dalam sikap, ucapan dan perbuatan Narapidana sehari-hari. e) Materi alQur'an-Hadis, Akidah Akhlak, Fikih, Sejarah Kebudayaan Islam dan Bahasa Arab ada pada seluruh kelas pada tingkat umur dan status kemampuan narapidana dengan menggunakan pendekatan integrated. Tujuannya untuk membentuk manusia yang menguasai ilmu pengetahuan, teknologi dan keterampilan yang religius (berjiwa dan berkarakter agama) dan berakhlak mulia, sehingga menjadi seorang ahli ilmu agama Islam yang kelak dapat menjadi bekal hidup setelah narapidana keluar dari Rutan atau kembali ke 
masyarakat. f) Penyusunan kurikulum Pembinaan PAI pada Rutan Salatiga ini sudah memenuhi ketentuan sebagaimana diatur dalam Undang-undang Nomor 20 Tahun 2003 tentang Sistem Pendidikan Nasional, dan Peraturan Pemerintah Nomor 19 Tahun 2005 tentang Standar Nasional.

\section{Analisa Kekurangan}

Adapun kekurangan yang terdapat pada Kurikulum PAI untuk Pembinaan Narapidana di Salatiga tersebut antara lain:

a. Belum memuat tentang prinsip-prinsip pengembangan Kurikulum yaitu :

1). Berpusat pada potensi, perkembangan, kebutuhan, dan kepentingan Narapidana dan lingkungannya. 2) Beragam dan terpadu.

2). Tanggap terhadap perkembangan ilmu pengetahuan, teknologi dan seni.

3). Menyeluruh dan berkesinambungan.

4). Belajar sepanjang hayat.

5). Seimbang antara kepentingan nasional dan kepentingan daerah.

Prinsip ini belum disebutkan secara menyeluruh dalam kurikulum, namun dalam pelaksanaannya sudah tercermin dalam kurikulum tersebut.

b. Belum mencantumkan tentang acuan operasional penyusunan Kurikulum. Hal yang perlu diperhatikan dalam penyusunan kurikulum di rutan Salatiga diantaranya adalah (i) keragaman potensi dan karakteristik daerah dan lingkungan, (ii) kondisi sosial budaya masyarakat setempat, (iii) tuntutan dunia kerja setelah Narapidana kembali ke masyarakat, (iv) perkembangan ilmu, (v) kesetaraan jender, (vi) dinamika perkembangan global dan (vii) persatuan nasional dan nilai-nilai kebangsaan 


\section{Manajemen Pembinaan Pendidikan Agama Islam di Rutan Salatiga}

Dari hasil penelitian yang dilakukan peneliti terkait dengan Pembinaan Pendidikan Agama Islam bagi Narapidana di Rutan Klas IIB Salatiga ditemukan bahwa pembinaan yang dilakukan pihak RUTAN dalam membina dan membimbing dibagi menjadi 2 bagian yaitu didalam ruangan dan diluar ruangan. Manajemen pembinaan Agama Islam yang sudah diterapkan di Rutan Klas IIB Salatiga ini secara umum sudah cukup efektif dan baik. Hal ini dapat dilihat dari sudah tersusunnya dengan baik tujuan pembinaan, jadwal pembinaan, materi pembinaan, kurikulum pembinaan serta petugaspetugas pembinaan sudah tertata dengan baik. Namun ada beberapa hal yang harus ditingkatkan berdasarkan wawancara dengan salah satu Pembina PAI.

"harapan saya walaupun saya memiliki ilmu yang sedikit semoga dapat bermanfaat pada narapidana agar tetap menjalankan kegiatan sesuai dengan ajaran agama dan aturan negara. Dan semoga masyarakat bisa mengorangkan dan menerima narapidana dan mau melanjutkan pembinaan dilingkungan masing-masing. Kepedulian dari semua pihak terhadap narapidana sangat dibutubkan di rutan salatiga sebingga pembinaan bisa berjalan dengan lancar dan dapat di implementasikan di masyarakat dan bisa bermanfaat untuk sesama dan menjadi orang yang lebih baik "

Penerapan manajemen pembinaan PAI di Rutan Klas IIB Salatiga adalah dengan cara menerapkan fungsi-fungsi manajemen yaitu perencanaan, pengorganisasian, pelaksanaan, dan pengawasan serta evaluasi.

\section{Perencanaan}

Perencanaan dimulai pada awal bulan Januari, hal ini terkait dengan anggaran yang akan dialokasikan yang akan dievaluasi pada setiap akhir tahun anggaran. Kegiatan diawali dengan rapat perencanaan dengan mengundang ustadz-ustadz yang terlibat dalam 
pembinaan PAI di Rutan Salatiga. Selanjutnya membagi kelas-kelas sesuai kemampuan narapidana.

\section{Pengorganisasian}

Agar pelaksanaan pembinaan PAI di rutan Salatiga terorganisasi dengan baik, maka dilakukan pembagian tugas yang disesuaikan dengan keahlian para petugas. Selain itu, dilakukan koordinasi dengan para petugas, dimana akan ditunjuk salah satunya untuk menjadi koordinator.

\section{Pelaksanaan}

Dari hasil observasi observasi membuktikan bahwa di Rutan Klas IIB Salatiga mengalami keterbatasan pada area tempat maka pendidikan agama Islam dilaksanakan di aula Rutan Salatiga dimana tempat itu juga dijadikan sebagai tempat multi fungsi. Metode pendidikan agama Islam di Rutan Salatiga berfariasi seperti yang telah ada dalam hasil penelitian melalui metode wawancara dengan narapidana, ustadz, dan ustadzah hal itu disebabkan karena ustadz dan ustadzah yang mendidik agama Islam bagi narapidana tidak tentu artinya tidak setiap pertemuan dalam agama Islam ustadz dan ustadzahnya selalu sama. Ustad/ustazahnya diambil dari Kemenag Salatiga. Dari Kemenag itulah yang memberikan pendidikan agama Islam kepada narapidana secara rutin dan bergantian pengajarnya.

Adapun dalam pelaksanaan pembinaan PAI Rutan Klas IIB Salatiga dilakukan setiap hari senin sampai kamis dengan pengisi materi dari pihak-pihak hasil kerjasama Rutan Klas IIB Salatiga dengan instansi lain yaitu Kementrian Agama Islam seperti yang sudah dijelaskan diatas. Pelaksanaan sudah terjadwal dengan baik supaya tidak terbentur dengan pelaksanaan pembinaan yang lain. Metode pembinaan PAI (Pendidikan Agama Islam) bagi narapidana di Rutan Klas IIB Salatiga pada dasarnya seperti apa yang diterapkan di luar Rutan, metode yang dilakukan kebanyakan menggunakan metode ceramah/siraman rohani dan Tanya jawab antara narapidana dengan narasumber atau pengajar. Metode yang diterapkan dalam 
Pembinaan Pendidikan Agama Islam di Rutan Klas IIB Salatiga antara lain ada:

1. Metode Ceramah

Metode ceramah dilakukan oleh Pembina-pembina yang sudah penulis sebutkan diatas sudah bisa diterima dengan baik oleh warga binaan hal ini terlihat dari antusias warga binaan yang mengikuti. Salah satu warga binaan yang bernama TT menyatakan

"Kehidupan saya sebelumnya jarang mengikuti pengajian, sholat bolong-bolong. Sejak kecil sudah di didik oleb orang tua dalam hal keagamaan dan sebelumnya sudah pernah khatam al-qur'an 2 kali setelah di rutan menjadi 6 kali khatam. Semua itu karena rutinnya pembinaan yang dilaksanakan di Rutan Salatiga"

\section{Metode Diskusi}

Dalam metode diskusi ustadz membagi kedalam beberapa kelompok, kemudaian ustadz memberikan pertanyaan kepada narapidana untuk dijawab secara bersama-sama dalam satu kelompok, selanjutnya ustadz menyuruh narapidana untuk mempersentasikan jawaban dari kelompok mereka didepan kelompok lain, ustadz memberikan kesempatan kepada kelompok lain untuk bertanya kepada kelompok yang persentasi waktu itu, kemudian dijawab oleh kelompok yang diberi pertanyaan, Selanjutnya ustadz memberikan kesimpulan dan jawaban dari pertanyaan narapidana, apabila ada jawaban dari narapidana yang belum jelas dan benar.

Dalam diskusi ini masih terdapat kendala dikerenakan warga binaan kurang respon karena keterbatasan mereka terhadap pemahaman agama. Mereka lebih menyukai metode ceramah dan tanya jawab

3. Pemberian nasihat

Pemberian nasihat dilaksanakan oleh pembina PAI dengan tujuan agar warga binaan menjadi lebih baik sehingga diharapkan terjadi revolusi mental terhadap narapidana. 


\section{Pengawasan}

Pengawasan adalah suatu rangkaian kegiatan yang harus dilakukan untuk mengadakan pengawasan, penyempurnaan dan penilaian untuk menjamin agar tujuan dapat dicapai seperti yang telah ditetapkan dalam perencanaan. Dalam pengendalian terdapat kegiatan monitoring hasil-hasil dan membandingkannya dengan standar, menentukan penyebab-penyebabnya, dan memperbaiki penyimpangan-penyimpangannya (Sutopo, 1998: 96). Pengawasan di Rutan Salatiga disamping dari pembina kerohanian juga melibatkan petugas keamanan Rutan. Kepala Rutan Salatiga menyatakan;

"bagi warga binaan yang tidak mengikuti program pembinaan yang dilaksanakan di Rutan maka saya beri sanksi diantaranya mengisi bak mandi, jalan bebek dan apabila masib tidak mengikuti kegiatan maka saya tidakakan menandatangani pengajuan PB (Pembebasan Bersyarat)"

Pengawasan dilakukan dengan cara adanya absensi berupa fingerprint sebagai dasar narapidana mengikuti program pembinaan lanjutan, salah satu warga binaan menyatakan;

"dalam mengikuti sholat jamah saya lebih takut dengan finger print, lebih baik saya mengikuti kegiatan daripada menerima sanksi mengisi bak mandi selurub kamar bunian dan jalan bebek"

Dari pengawasan ini terlihat sudah terjadi revolusi mental narapidana di Rutan Salatiga yang awalnya narapidana mengikuti pembinaan karena keterpaksaan menimbulkan kesadaran diri dalam beragama karena pembiasaan yang diterapkan di Rutan Salatiga.

\section{Penutup}

Berdasarkan hasil penelitian yang dilakukan dapat disimpulkan bahwa pembinaaan Pendidikan Agama Islam bagi Narapidana di Rutan Klas IIB Salatiga sudah menggunakan kurikulum sendiri. Kurikulum yang diterapkan telah mengikuti pengertian kurikulum yang diajukan oleh Dewantara (2003), Nasution (2008) maupun UU No. 20 Tahun 2003. Kurikulum Pembinaan PAI tersebut telah 
diterapkan dengan baik oleh petugas Rutan Salatiga dengan memperhatikan komponen-komponen kurikulum yang diajukan oleh Sukmadinata (1997), Sadulloh (1994), Febriyanti (2013) dan juga UU No. 20 Tahun 2003. Dengan demikian proses revolusi mental, terjadinya perubahan perilaku maupun sikap para narapidana tersebut dapat terlihat secara umum. Walaupun, tidak mengingkari ada yang melakukan perubahan tersebut karena unsur terpaksa. Metode pembinaan dilakukan dua cara yaitu di dalam dan di luar ruangan. Diantara dengan cara ceramah, diskusi, tanya jawab, bimbingan dan pemberian nasehat.

Pencapaian atas hasil pembinaan Pendidikan Agama Islam Rutan Salatiga ini, tentu tak lepas dari peran para pembinanya dalam mengelola manajemen pelaksanaan program pembinaan PAI tersebut. Pengajar, Pembina program Pembinaan PAI ini juga melakukan pengawasan terhadap pembinaan yang dilakukan dengan cara pemantauan dan evaluasi hasil pembinaan yang nantinya menjadi barometer penilaian terhadap narapidana layak tidaknya mendapat pembinaan lanjutan seperti PB (Pembebasan Bersyarat). Berdasarkan analisis kelebihan dan kekurangan yang ditemukan dalam penelitian ini, maka perlu dilakukan peninjuan ulang kurikulum Pembinaan PAI di Rutan Salatiga agar pencapaian revolusi mental narapidana dapat lebih intensif dan bermanfaat lebih luas lagi. 


\section{Daftar Pustaka}

Appelbaum, Paul. 1994. Almost A Revolution. Mental Health Law and the Limits of Change. Inggris: Oxford University Press.

Astuti, Ari. 2011. Pembinaan Mental di Lembaga Pemasyarakatan Wirogunan. Tesis. FKIP: Universitas Ahmad Dahlan.

Bambang, Indriyanto.,2014. Mengkaji Reolusi Mental dalam Konteks Pendidikan". Pendidikan dan Kebudayaan, Volume 20, No 4 (Desember 2014), 556.

Bayung, Syakroa, 2016. Paradigma Implementasi Konsep Revolusi Mental, Elementary Volume 2 Edisi 3 Januari 2016

Daniel, Agustinus. 2014. Mental revolution. A Small Change For A Better Civilization. GMRN. Indonesia.

Darminta. 2006. Prasktis Bimbingan Rohani. Yogyakarta: Kanisius.

Departemen Agama RI. 2002. Al-Qur'an dan Terjemahannya. Depok : Al Huda.

Depdiknas. 2003. Undang-undang RI nomor 20 tahun tentang system pendidikan Nasional, Jakarta.

Dwidja, Priyatno. 2006. Pidana Penjara di Indonesia. Bandung: Refika Adiana.

Febriyanti, 2013. Kurikulum Pendidikan Tinggi di Era Globalisasi. TA'DIB, Volume XVIII, No 02 (November 2013), 298.

Gholib, Ahchmad. 2006. Studi Islam Pengantar Memehami Agama, AL-Qur'an, Al-Hadits, dan sejarah Peradaban Islam. Jakarta: Faza Media.

Hajar, Dewantoro. 2003. Pengembangan Kurikulum Pendidikan Agama Islam, Jurnal JPI FIAI Jurusan Tarbiyah, Vol IX, No 6 Desember 2003, 49.

Hasan Alwi, dkk. 2005. Kamus Besar Bahasa Indonesia. Jakarta: Pendidikan Nasional Balai Pustaka.

Huberman, Matthew. 1989. Qualitatif Data Analisis. Jakarta: Bulan bintang. 
Kementrian Koordinator Bidang Pembangunan Manusia dan Kebudayaan. Sosialisasi Gerakan Nasional Revolusi Mental. Jakarta: 2015.

Keputusan Menteri Kehakiman RI Nomor: M.02-PK.04.10

Majid, Abdul dkk. 2006. Pendidikan Agama Islam Berbasis Kompetensi. Bandung: PT. Remaja Rosdakarya.

Mulyasa, H. 2015. Revolusi Mental dalam Pendidikan. Bandung: PT Remaja Rosdakarya.

Muhaimin, dkk. 1993. Pemikirnan Pendidikan Islam. Bandung: Tri Ganda Karya.

Muhammad Kristiawan, 2015. Telaah Revolusi Mental dan Pendidikan Karakter dalam Pembentukan Sumber Daya Manusia Indonesia yang Pandai dan Berakhlak Mulia. Jurnal Ta'dib, Volume 18, No1 Juni 2015, 15.

Munandar, A. 1993. Pembinaan dan Masalahnya. Jakarta: Gunung Agung.

Maelong, Lexy. 1989. Metode Penelitian Kualitatif. Bandung: Remaja Karya.

Nasution. 2008. Kurikulum dan Pengajaran. Jakarta : Bumi Aksara.

Nizar, Samsul. Filsafat Pendidikan Islam Pendekatan Historis, Teoritis, dan Praktis. Jakarta: Ciputat Press.

Peraturan Menteri Hukum dan HAM RI.Nomor M. 01. PK.04-10. 2017.

Peraturan Pemerintah RI Nomor 31 Tahun 1999.

Peraturan Menteri Agama RI Nomor 2 Th 2008 tentang Standar Kompetensi Lulusan dan Standarisasi Pendidikan Agama Islam dan Bahasa Arab di Madrasah. Jakarta: Depag, 2008.

Poerwadarminta. 1987. Kamus Besar Bahasa Indonesia Edisi Ketiga. Jakarta: Balai Pustaka.

Putra S, dkk, 2015. Pembinaan Mental narapidana di Lembaga Pemasyarakatan Anak Klas II A Blitar (Studi Kasus). Tesis, UIN Maulana Malik Ibrahim Malang. 
Sugiyono. 2004. Metode Penelitian Pendidikan Kuantitatif, Kualitatif, dan R\&D. Bandung: Alfabeta.

Sutopo. 1998. Administrasi Manejemen Organisasi. Jakarta: LAN RI. Thoha, Miftah. 2003. Pembinaan Organisasi: Proses Diagnosa dan Intervensi. Jakarta: Raja Gradindo Persada.

Tim Dosen FIP IKIP Malang. 1980..Pengantar Dasar-Dasar Kependidikan. Surabaya: Usaha Nasional.

Undang-undang, tentang Sitem Pendidikan Nasional. No 20 th.2003.

Undang-undang nomor 12 tahun 1995 tentang Pemasyarakatan.

Sadulloh, Uyoh. Pengantar Filsafat Pendidikan. Bandung: PT. Media Iptek. 